\title{
A Summary of the Work done by the Liverpool Marine Biology Committee during 1885-87.
}

\section{By Professor W. A. Herdman, D.Sc., F.L.S.}

The Liverpool Marine Biology Committee was formed in March, 1885, for the purpose of investigating thoroughly the Fauna and Flora of Liverpool Bay and the neighbouring parts of the Irish Sea. The aim of the Committee is not merely to draw up an accurate list of the species found in this locality, but also to observe and record the relative numbers, the size, the colours, and the condition generally of the specimens, the exact localities in which they are found, the other species of animals and plants associated with them, and their mutual relations as food, enemies, or competitors. In this way it is hoped that a mass of observations will be accumulated which may be of use in determining the geographical distribution of various forms, the nature of the conditions which influence species, and the relations existing between the different plants and animals. It was felt at the outset that this work was exactly that department of biological investigation which could be best carried out by an organised body of workers who would subdivide the area to be investigated, and the groups of animals and plants to be worked up between them, and would carry on systematic observations year after year, sending in periodic reports upon their work. The value, in fact the absolute necessity, of this organisation, division of labour, and systematic arrangement, for the successful accomplishment of the objects in view, has been felt all along by the members of the Committee and those naturalists who have worked with them; and the results attained so far have, I think, fully justified their belief in the benefit to be derived from scientific organisation.

The operations of the Committee have been carried on 
now for three seasons, and the practical part of the work has consisted of dredging expeditions, lasting in some cases for several days at a time, tow-netting expeditions in small boats, and shore expeditions for the investigation of the littoral Fauna. A considerable extent of the large quadrangular area* of the Irish Sea extending around Liverpool Bay, and bounded by the Isle of Man and the coasts of Anglesey, North Wales, Cheshire, and Lancashire has now been explored, large collections have been made, and a first volume of reports $\dagger$ has been published consisting of twentynine articles written by twenty-one biologists and illustrated by ten plates and two maps of the district. These reports record the occurrence of 913 species, $\ddagger$ of which at least 235 had not been found previously in this neighbourhood. Sixteen of these species have not been previously discovered in British seas, and at least seven species and three varieties are new to science, so that a considerable measure of success has already attended the efforts of the Committee. It is evident, however, that such work must be a matter of time, and that every additional year's records will add to the value of any conclusions that may be drawn in regard to the Fauna under consideration.

The records already made have attracted attention to several general questions which are now being investigated.

One of these is the detection of changes in the local Fauna which have taken place, or may take place in the future. Some of the rarer Nudibranchs, such as Embletonia pallida and Antiopa hyalina, formerly found on the shores of Hilbre Island at the mouth of the Dee, have probably disappeared entirely from that locality. On the other hand, the rare Hydroid Garveia nutans seems to have migrated lately into Liverpool Bay, and to be spreading there with rapidity. It was first noticed in this neighbourhood on May 9th, 1885, while dredging in Hilbre Swash, and since then has been found at Hilbre Island, Colwyn Bay, off Puffin Island, and

* Generally called for short in the Reports, the L. M. B. C. district.

+ 'First Report upon the Fauna of Liverpool Bay,' \&c., Longmans, London, 1886 .

¥ Since increased to over a thousand species. 
in various other parts of the district. The Hydroid Fauna had been so carefully investigated for many years previous to 1885 by excellent observers that this conspicuous species could scarcely have escaped observation if it had been present in the neighbourhood. It is interesting to find that Professor Haddon has recorded Garveia nutans as having made its appearance in Dublin Bay for the first time also in 1885 .

The distribution of the various species of the littoral Fauna, according to the distance above low-water mark, is of importance on account of the influence which the position on the shore must have upon the habits and mode of life of the animals. The Polyzoon Flustrella hispida has been found at Hilbre Island, living and healthy, about one yard below highwater mark, in such a position that it could only have an opportunity of being covered by the sea and of taking in food during two short periods in each twenty-four hours, and must be exposed to the air during about five-sixths of its existence.

During the second season (1886) it became obvious to the Committee that in order to advance further in their work, so as to be able to make more minute explorations, and to carry on detailed investigations into the habits and lifehistories of the animals, it would be necessary to establish a small observing station or marine laboratory at some suitable spot in the district. After some preliminary inquiries they decided upon Puffin Island, off the north entrance to the Menai Straits, and were fortunately able to obtain from Sir Richard Bulkeley the use of the old Dock Board Signalling Station, which stands upon the seaward or north-east point of the island. This building has now been converted into a simple but efficient Biological Station* capable of accommodating about half-a-dozen workers at a time. The shores of Puffin Island are rocky and support an abundant Fauna, and good dredging ground is present in the immediate vicinity. The Puffin Island Station was established early in the summer of 1887 , and has been open continuously since

* For a description, with figures, see 'Nature,' July 21st, 1887. 
then*. It has already shown itself to be of great value to the Committee by enabling them to live for a few days or weeks at a time in the centre of the richest Fauna of the district, and by giving them facilities for undertaking work which could not otherwise have been done. Moreover, the keeper of the station is constantly employed in collecting animals, and in dredging when possible; and he has been able to provide the Committee with a continuous series of surface tow-nettings extending throughout the autumn and winter, and taken in some cases during the night. These are being worked up by Mr. I. C. Thompson, F.L.S., and have already yielded several points of interest; for example, the parasitic Copepod Trebius caudatus has only been taken in the tow-net during the night, and appears to be then freeswimming. Another interesting parasitic Copepod, Lichomolgus sabellæ, new species, was first found last summer near Puffin Island attached to the branchial plumes of the Annelid Sabella penicillus.

Some parts of the L. M. B. C. district are particularly good localities for Nudibranchiate Mollusca. Forty-two species were recorded in the report published in 1886, and since then members of the Committee have found several additional species, including Fiona nobilis. The rocks at Hilbre Island and Puffin Island are especially good collecting ground, but the assemblage of Nudibranchs on the shore is very different at different times of the year. There is no doubt, from the observations of the Committee, that the Nudibranchs migrate in large numbers at certain times into the littoral zone, and then after a time disappear again into the deep water. They seem to come on shore primarily for spawning purposes, but may be influenced by other circumstances also.

In the other groups the chief results obtained are as follows:

In the Protozoa, the Foraminifera alone have been fully worked up. One hundred and sixty-two species have been found, including three new to science, viz. Placopsilina

* For a summary of the work done at the station during the first year, see 'Proc. Liverpool Biol. Soc.,' vol. ii, p. 38, 1888. 
Kingsleyi (Siddall), Reophax moniliforme (Siddall), and Miliolina spiculifera (Siddall). Forty species of Sponges are recorded, including two new forms, Aphroceras ramosa (Carter), and Sycandra aspera (Gibson). A very large number of Hydromedusæ have been found and examined. The most important form is Garveia nutans (Wright), referred to above. Amongst the Actinozoa is a new variety of Cylista undata (Müller), and Sarcodictyon catenata (Forbes), which has been found living and kept under observation for some time. The Echinodermata and the Vermes, although numerous, have as yet yielded nothing remarkable. Over a hundred species of Polyzoa have now been recorded by the Committee, including at least one new species, Ascopodaria nodosa (Lomas), allied to Pedicellina. The Copepoda, as a result of the regular tow-nettings taken round Puffin Island by the keeper of the Biological Station, and sent to Mr. Thompson for examination, have been very numerous, and have included a large number of rare and interesting forms of which some are new to British seas, and the following have been described as new species :

Cyclops puffini (Thompson), Lichomolgus sabellæ (Thomps.), Cymbasoma herdmani (Thomps.), and several others still unpublished. Amongst the higher Crustacea Mr. A. O. Walker, F.L.S., has recorded some rare northern forms of Amphipoda, four species of Schizopoda, two of Cumacea, and a large number of Decapoda. The Pycnogonida collected contain several rare forms, and one, still undescribed, which is probably new to science. The Nudibranchiata have been already referred to above; the lists of other Mollusca present nothing of special importance. The report upon the Tunicata deals with forty-seven species of which at least two (Morchellioides alderi, Herdman, and Polycarpa monensis, Herdm.) are new to science, while seven have not been previously recorded from British seas. Nineteen of the species are simple Ascidians, twenty-seven are compound, and the remaining one is the pelagic Oikopleura flabellum.

Several preliminary lists of the Algæ of the district have been drawn up, and the whole group is now in the hands of Mr. R. J. Harvey Gibson, Lecturer on Botany in University 
College, Liverpool, who is at present systematically examining the seaweeds growing on the shores of Puffin Island. The Fishes have not yet been systematically worked up, and the Committee have not undertaken any economic investigations, their object being in the first place to make a complete examination of the L. M. B. C. district for purely scientific purposes.

In conclusion, I would emphasise my opinion that such biological work as the investigation of the Fauna and Flora and the physical conditions of a district can be carried out best by a small body of naturalists, such as the Liverpool Marine Biology Committee, subdividing the work, devoting themselves to their special groups, but working together as much as possible so as to keep thoroughly in touch with their fellow-workers, and to understand the scientific bearing of their results and observations. Such bodies of naturalists should be easily organised in all populous maritime districts where there are teachers of Biology and Scientific Natural History Societies. There is abundance of work for them to do on almost every part of our coast line. Liverpool Bay has not a specially rich Fauna. In fact it is distinctly poorer than some other districts, such as the estuary of the Clyde, and yet the Committee here feel that they have little more than commenced their work. A laboratory, however small, placed close to the scene of operations, is a most important addition in marine investigations; and it is not too much to hope that each of our Universities, Colleges, and more important scientific societies situated within reach of the sea will in course of time establish its own Marine Station as a necessary adjunct to its Biological Department. 


\section{The Scottish Marine Station and its Work. \\ By William F. Hoyle, M.A.}

The "Scottish Marine Station for Scientific Research" has now been at work for a little over four years, so that the present seems a fair opportunity to inquire what has been accomplished by its means. The object of the present article is to supply this information, and to show to what extent the results obtained have justified the expectations of its promoters.

It may be well at the outset to lay before the reader in a few words the circumstances which led to the establishment of this institution, as well as the means which have been at its disposal. The nucleus of its pecuniary resources was a sum of $£ 1400$, the surplus from the Edinburgh Fisheries Exhibition of 1882, which was handed over to the Scottish Meteorological Society for the purpose of carrying on investigations which they had already commenced into the herring and other fisheries, "with power to establish a zoological station and also to endeavour to get Government to assist them in the work." The application to Government for assistance was unsuccessful. Dr. John Murray, of the "Challenger" expedition, however, offered to found a zoological station, and to maintain it for at least three years, provided the Council of the Society would give him an annual grant from the fund of $£ 250$ for these years. This offer was accepted, and on April 14th, 1884, the Institution was inaugurated, and systematic work commenced. At the outset Dr. Murray received assistance from friends and others interested in the work, and has also received grants from the British Association, and the Government Grant Committee.

The station had its head-quarters in the old quarry at Granton, about two miles and a half distant from Leith, 